\title{
An evaluation of Islamic moral teaching for students of Madrasah Aliyah Negeri (MAN)
}

\author{
${ }^{* 1}$ Siti Amanah; ${ }^{2}$ Haryanto \\ ${ }^{1}$ Graduate School of Universitas Negeri Yogyakarta \\ Jl. Colombo No. 1, Depok, Sleman 55281, Yogyakarta, Indonesia \\ ${ }^{2}$ Faculty of Education, Universitas Negeri Yogyakarta \\ Jl. Colombo No. 1, Depok, Sleman 55281, Yogyakarta, Indonesia \\ *Corresponding Author. E-mail: sitia7001@gmail.com \\ Submitted: 14 March 2018 | Revised:09 April 2018 | Accepted: 09 April 2018
}

\begin{abstract}
This research is aimed at evaluating: the preparation, implementation, and outcome of the moral teaching program using Stake Countenance evaluation model (antecedent, implementation, and outcome). The study was conducted at Madrasah Aliyah Negeri (MAN) Cilacap, MAN Kroya, and MAN Majenang. The subjects were the principals, teachers of Aqidah Akblak, chairpersons of the Madrasab Committee, and 276 grade XII students. Interview, observation, questionnaire, and documentation were used as data collection techniques. The data analysis method used was the quantitative-qualitative descriptive analysis. The result of the evaluation shows that: (1) the preparation of the moral teaching is in 'good' category; (2) the implementation of moral teaching in terms of time and methods is in 'good' category, but the model of moral judgments used is not in 'good' category; (3) the result of moral teaching in the madrasah and outside the madrasah as a whole is in 'good' category. Thus, Islamic moral teaching evaluation of MAN in Cilacap Regency viewed from the preparation, implementation, and the result is in accordance with the evaluation criteria. In addition, there is a need for further action to examine the effectiveness of moral teaching in madrasabs.
\end{abstract}

Keywords: evaluation, moral, stake countenance

\section{Introduction}

According to Surah Al Baqarah [2]: 30, Allah Subhānahu wa-ta'ālā (SW'T) created men to be the viceroy (leader) of the earth (Indonesian Department of Religious Affairs, 2011, p. 6). A good leader is a leader who provides examples through goodness and nobility of his/her soul and manner. Since the very beginning, education (both formal and nonformal ones) has played a fundamental role for human because it is the mean to bolster his/her level of knowledge and mannerism or in Arabic, akblaq. According to the $\mathrm{Na}$ tional Education System Law, the goal of education is to enlighten a nation, develop the potentials, and build a healthy national civilization possessing manners and God-fearing attitude. Therefore, men of manners are symbols of success in education.

Etymologically, akblaq comes from an Arabic word al akblaq which is the plural form of khuluqun or ethical conduct, good attitude, good manner, or disposition (Ya'qub, 1991, p. 11). There are many verses of the Holy Quran that focus on akblaq. One of them is Verse 4 in Chapter 68 which says:

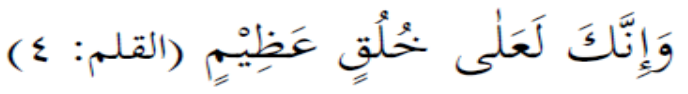

In English: 'And verily, you (Muhammad Sallallaahu Alaihi Wasallam) are on an exalted standard of character'. (Al-Qalam [68]: 4).

Al-Qalam [68]: 4 indicates that Allah SWT has chosen the best man, Prophet Muhammad Sallallaabu Alaibi Wasallam (SAW), as the example for mankind. There- 
fore, it is mandatory to follow his teachings as indicated in the following hadith.

$$
\text { إنمابعثت لأنتمح مكارم الأخلاق }
$$

Prophet Muhammad SAW said: 'I have been sent to perfect good character' (Abas, 1437, p. 7).

Perfect character is an achievement that is only possible through tireless work from both parents and other family members in educating their closest relatives (Daradjat, 2000 , p. 35). Education starting from the family is essential in developing a child's character. Further, other parts of the community, such as close friends, colleagues, and other acquaintances, have to take part in the character (akblaq) education (Zuchdi, 2013, p. 20).

Focusing on achieving the key functions and goals of education, schools or madrasas play an important role in producing human resource possessing elevated level of intelligence, manner and morality, providing excellent example to be followed. Darmayanti and Wibowo (2014, p. 227) state that schools are means to deliver strategic program and tackle the existing moral problems. At schools or madrasas, the process to achieve students' elevated level of mannerism might involve several curricular and extracurricular activities. The curricular activities are the activities in Islamic moral teaching and learning activities, while the extracurricular activities are religious discussion forum, Islamic holiday celebration, and also pilgrimage to Mecca. The importance of those activities lays in the fact that the learning process and religious atmosphere affect the students' learning behavior and the fact that the result of the study is heavily affected by the religious atmosphere at the schools (Kartowagiran \& Maddini, 2015, p. 995).

Furthermore, the teachers' tenacity and leadership are also the key factors to the success of Islamic moral teaching (akblaq teaching). As professional educators, teachers perform their main tasks including teaching, educating, fostering, guiding, directing, counseling, training, assessing and evaluating students in the levels of early-childhood, elementary, and secondary education (Kartowagiran, 2011, p. 464). Therefore, the professional teachers will be able to facilitate the students to construct good manner and habit.

As an Islamic education institution, Madrasah Aliyah Negeri (State Islamic Senior High School/MAN) in Cilacap Regency, Central Java, Indonesia has put forward religious education by focusing on producing students with good manners (good akblaq) and high achievement so that they are excellent at science and technology. As a follow up, madrasas have taken many actions. However, in my opinion, many of the factors have not been properly assessed. These factors are (1) available resources, (2) religious curricular and extracurricular activities, (3) applicable learning methods, (4) an applicable evaluation model, (5) the goal and scope of the mannerism being built. Additionally, even-though the strategic plan had been arranged, the achievement of the activities enforcement supporting the programs had not been well arranged. Based on the observation, it was known that (1) the teachers were not consistent in preparing the lesson plan device for Islamic moral teaching (akblaq/character building), (2) the teachers did not rely on the standards of character (akblaq) evaluation in evaluating the students, and (3) the process of evaluation conducted by the teacher was not systematic. Therefore, the evaluation on Islamic moral teaching at MAN was highly needed to find out the imperfect parts of the implementation of Islamic moral teaching in Cilacap Regency.

In this context, evaluation is a set of practices to determine the quality, performance, and productivity of an institution in the implementation of its programs (Mardapi, 2012, p. 4). It is also noted that Evaluation is the determination of the worth of the thing. It includes obtaining information for use in judging the worth of a program, product, procedure, or objective, or the potential utility of alternatives approaches designed to attain specified objectives' (Worthen \& Sanders, 1973 , p. 19). The evaluation aims to answer the following questions: (1) How are the Islamic moral teaching programs prepared; (2) How are the Islamic moral teaching programs executed; and (3) What is the result of Islamic moral teaching at MAN in Cilacap Regency like? 


\section{Method}

The research was conducted from February to August 2016. The evaluation of the Islamic moral teaching was conducted in three MAN's in Cilacap Regency: MAN Cilacap, MAN Kroya, and MAN Majenang. The research setting was determined based on the similarities among these schools in terms of the implementation of the Islamic moral teaching programs.

The subjects of the evaluation were grade XII students, Madrasas' principals, teachers of Aqidah Akblak (Islamic Creed and Mannerism) and the heads of madrasa committee. The research sample was established using purposive sampling technique by considering the competence and role. Table 1 shows the number of the involved respondents. Random sampling technique with Slovin's formula was applied to proportionally select 276 respondents out of 806 students (see Table 2.)

\section{Data Collection Techniques}

This was an evaluation research implementing quantitative and qualitative approach. This research employed Stake Countenance evaluation model consisting of three stages of evaluation: preparatory stage (antecedent), implementation stage (transaction), and result stage (outcome).

In this research, there were two types of data: quantitative and qualitative data. The quantitative data were collected using a questionnaire, whereas the qualitative data were gathered through interviews with the madrasa principals, teachers, and the head of the madrasa committees. The data collected through observation and documentation were used to support the result of the analysis on quantitative and qualitative data. Table 3 shows the data collection techniques used.

Table 1. The number of respondents consisting of the madrasa principals, teachers and the head of the madrasa committees

\begin{tabular}{lccc}
\hline MAN & The Madrasa principals & Teachers & The Head of Committee \\
\hline MAN Cilacap & 1 & 1 & 1 \\
MAN Kroya & 1 & 1 & 1 \\
MAN Majenang & 1 & 1 & 1 \\
Total & $\mathbf{3}$ & $\mathbf{3}$ & $\mathbf{3}$ \\
\hline
\end{tabular}

Table 2. The number of respondents from students

\begin{tabular}{cccc}
\hline MAN & Number of Students & $\mathbf{\%}$ & Number of Respondents \\
\hline MAN Cilacap & 238 & 30 & 70 \\
MAN Kroya & 231 & 28 & 65 \\
MAN Majenang & 337 & 42 & 141 \\
Total & $\mathbf{8 0 6}$ & $\mathbf{1 0 0}$ & $\mathbf{2 7 6}$ \\
\hline
\end{tabular}

Table 3. Data collection techniques

\begin{tabular}{|c|c|c|}
\hline Aspects & Indicators & Techniques \\
\hline $\begin{array}{c}\text { Preparatory } \\
\text { (antecedent) }\end{array}$ & $\begin{array}{l}\text { - Resources } \\
\text { - Goals and scopes of Islamic moral teaching (akhlaq teaching) } \\
\text { - The management of the infrastructures }\end{array}$ & $\begin{array}{l}\text { Interviews } \\
\text { Documentation } \\
\text { Observation }\end{array}$ \\
\hline $\begin{array}{l}\text { Implementation } \\
\text { (transaction) }\end{array}$ & $\begin{array}{l}\text { - Implementation time } \\
\text { - Islamic moral teaching methods } \\
\text { - Character evaluation models }\end{array}$ & $\begin{array}{l}\text { Interviews } \\
\text { Documentation } \\
\text { Observation } \\
\text { Questionnaire }\end{array}$ \\
\hline Results (outcome) & $\begin{array}{l}\text { - The application of Islamic morality by the students in the area of } \\
\text { the madrasas } \\
\text { - The application of Islamic morality by the students outside the area } \\
\text { of the madrasas }\end{array}$ & $\begin{array}{l}\text { Interviews } \\
\text { Documentation } \\
\text { Observation } \\
\text { Questionnaire }\end{array}$ \\
\hline
\end{tabular}


The goals of the preparatory stage (antecedent) were to gain insights into resources, purposes, scope of the material, and management of the infrastructures. The implementation stage (transaction) included evaluation on the implementation time, methods used, and evaluation models used. The result stage (outcome) aimed at understanding the application of Islamic morality by the students in the madrasas area. The data concerning these stages were collected through interviews, observations, document analysis, and questionnaire.

In order to better understand the above stages, the researchers conducted interviews with the madrasa principals, the head of the madrasa committees, and the teacher of Aqidah Akblak for the twelfth grade students. The preparatory aspect was essential in revealing resources, goals, scopes of the materials, and the management of the infrastructure. Moreover, the indicators for resources were the strategic plans and competence of the teachers in delivering Islamic moral teaching (akblaq teaching). In the aspect of implementation, the interviews aimed at revealing the implementation time of the Islamic moral teaching and the methods and evaluation of the education applied. The last stage (evaluation stage) was designed to reveal the application of Islamic morality by the students inside and outside the area of the madrasas.

There were three evaluators in three different MAN's to understand the infrastructures, process of teaching and learning of the subject of Aqidah Akblaq in madrasas, time of the Islamic moral teaching, and the methods used to build good characters in the students. The evaluators conducted documentation to gather supporting data for the preparation, implementation, and result of the Islamic moral teaching at MAN's in Cilacap Regency. The documentation specifically gathered the data concerning resources, materials, infrastructures of the madrasas, and curricular and extracurricular activities related to Islamic moral teaching in the madrasas.

As a part of the evaluation process, the authors distributed questionnaire to 276 students. The goal was to gather the students' responses to the components of the implementation of the Islamic moral teaching, the methods of the Islamic moral teaching, the models of the evaluation, and the application of Islamic morality by the students inside and outside the area of the madrasas.

\section{Validity of the Instruments}

The validity of the content was a means to understand the accuracy of the instruments of the observation, interviews, and questionnaire conducted by three experts in the field of education research and evaluation. The validity of the content was measured using Aiken $\mathrm{V}$ formula. Table 4 shows the content validity of the observation sheet.

Table 5 shows the analysis result of the content validity of the interview instruments. Meanwhile, Table 6 shows the analysis result of the content validity of the questionnaire.

Table 4. The result of $\mathrm{V}$ value in the content validity of the observation sheet

\begin{tabular}{ccccc}
\hline V Value & V Value in Table & Items No. & Items Numbers & Description \\
\hline 1 & 0.81 & $2,7,9$ & 3 & Valid \\
0.89 & 0.81 & $1,3,4,5,7,8$ & 6 & Valid \\
& Total & & $\mathbf{9}$ & Valid \\
\hline
\end{tabular}

Table 5. The result of $\mathrm{V}$ value in the content validity of the interviews instruments

\begin{tabular}{ccccc}
\hline V Values & V Value in the Table & Items No. & Items Numbers & Desc. \\
\hline 1 & 0.68 & $5,7,12,16,19,27,34$ & 7 & Valid \\
0.89 & 0.68 & $1,2,3,4,6,9,10,11,13,14,15,17,18,20$, & 39 & Valid \\
& $22,23,26,29,30,31,32,33,36,37,38,40,42,43$, \\
& $44,46,47,48,50,51,53,54,55,56,57$ \\
0.78 & 0.68 & $8,21,24,25,28,35,39,41,45,49,52$ & & \\
& & & 11 & Valid \\
& & Total & $\mathbf{5 7}$ & Valid \\
\hline
\end{tabular}


Construct Validity was used to reveal the accuracy of the construction of the questionnaire, which was measured with exploratory factor analysis (Retnawati, 2016, p. 42). The result of the construct validity analysis is shown in Table 7.

Table 7. KMO and Barlett's test result

\begin{tabular}{|c|c|c|}
\hline \multicolumn{3}{|c|}{ KMO and Bartlett's Test } \\
\hline $\begin{array}{l}\text { Kaiser-Meyer-Ol } \\
\text { Sampling Adequa }\end{array}$ & $\begin{array}{l}\text { in Measure of } \\
\text { cy. }\end{array}$ & .614 \\
\hline \multirow{3}{*}{$\begin{array}{l}\text { Bartlett's Test of } \\
\text { Sphericity }\end{array}$} & Approx. Chi-Square & 1475.660 \\
\hline & Df & 780 \\
\hline & Sig. & 0.000 \\
\hline
\end{tabular}

It can be concluded that the instruments of the Islamic moral teaching evaluation were valid for data collection. Out of 50 items in the questionnaire, there were 10 items with Anti-image Correlation value $<0.5$. The items were items $10,12,16,20,30,43$, 44, 45, 46 and 49. Thus, there were 40 valid items in the questionnaire.

\section{Reliability of the Instruments}

The reliability index of the instruments was considered acceptable if the reliability value was $>0.7$ (Linn, 1989, p. 106). The reliability of the observation sheets was estimated using the ICC (Intraclass Correlation Coefficient) formula. Generally, the result of observation sheet ICC analysis based on the rater was at 0.895 and the result of the evaluation on each rater was at 0.740 . Based on the estimation, the instruments were deemed to be reliable and valid for conducting the research. Table 8 shows the reliability of the observation sheets.

The estimation of the questionnaire reliability was conducted with Alpha Cronbach coefficient formula supported with the SPSS program. Based on the estimation result, the coefficient value of the Cronbach's Alpha was at 0.867 or higher than 0.7. Therefore, the questionnaire was deemed reliable (see Table 9).

Table 9. Reliability of the Alpha Cronbach

\begin{tabular}{cc}
\hline \multicolumn{2}{c}{ Reliability Statistics } \\
\hline Cronbach's Alpha & N of s \\
0.867 & 40 \\
\hline
\end{tabular}

Data Analysis Techniques

This research employed quantitativequalitative descriptive analysis. Each technique is described in the following sections.

\section{Quantitative Data Analysis}

Quantitative data analysis was used to describe the data collected through the questionnaire based on the score. The scores were categorized using normal distribution. The categorization was conducted with normal curve as the reference with the measurement of mean ideal (Mi) and standard deviation (SDi) (Mardapi, 2008, p. 123). The score categorization of the students is shown in Table 10.

Table 6. The result of $\mathrm{V}$ values in the content validity of the questionnaire

\begin{tabular}{ccccc}
\hline V Value & V Value in Table & Item no. & Item Numbers & Desc. \\
\hline 1 & 0.68 & $1,3,5,7,8,10,16,17,19,21,22,24,25,28,29,30$, & & Valid \\
& & $31,34,35,37,40,42,43,47,50$ & & \\
0.89 & 0.68 & $2,4,6,9,11,12,13,14,18,23,26,27,32,33,36,38$, & 22 & \\
& & $39,41,45,46,48,49$ & & \\
0.78 & 0.68 & $15,20,44$ & 3 & Valid \\
& & & $\mathbf{5 0}$ & Valid \\
\hline
\end{tabular}

Table 8. The result of observation sheet ICC

\begin{tabular}{|c|c|c|c|c|c|c|c|}
\hline \multicolumn{8}{|c|}{ Intraclass Correlation Coefficient } \\
\hline & Intraclass & \multicolumn{2}{|c|}{$95 \%$ Confidence Interval } & \multicolumn{4}{|c|}{ F Test with True Value 0} \\
\hline & Correlation & Lower Bound & Upper Bound & Value & df1 & $\mathrm{df} 2$ & Sig \\
\hline Single Measures & $.740 \mathrm{a}$ & .406 & .927 & 9.538 & 8 & 16 & .000 \\
\hline
\end{tabular}


Table 10. The categorization of the Islamic moral teaching result

\begin{tabular}{clc}
\hline No. & \multicolumn{1}{c}{ Score } & Category \\
\hline 1. & $\bar{X}+1,5 S B x \leq X$ & Very Good \\
2. & $\bar{X} \leq X<\bar{X}+1,5 S B x$ & Good \\
3. & $\bar{X}-1,5 S B x \leq X<\bar{X}$ & Poor \\
4. & $X<\bar{X}-1,5 S B x$ & Very Poor \\
\hline Description: & \\
$\bar{X}$ & $:$ average of total score \\
$S B x$ & : standard deviation of total score \\
$X$ & $:$ score achieved
\end{tabular}

\section{Qualitative Data Analysis}

The qualitative data analysis was used by implementing the interactive and sustainable analysis model of Miles and Huberman which consisted of four stages: data collection, data description, data reduction, and data verification/conclusion. Figure 1 schematically shows the analysis process of the qualitative data.

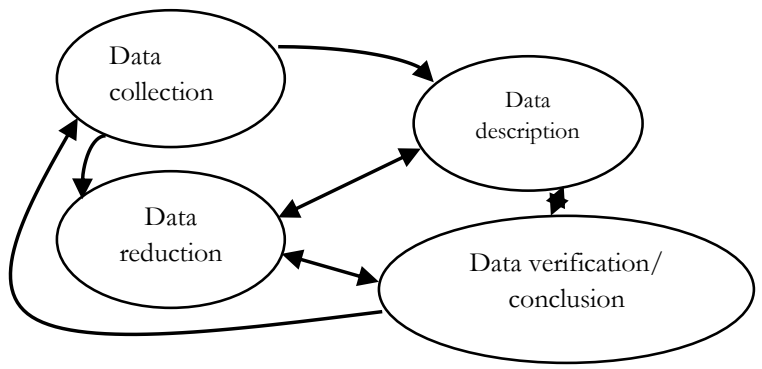

Figure 1. Analysis model of qualitative data (Miles \& Huberman, 1994)

\section{Findings and Discussion}

The Preparation for Islamic Moral Teaching (Akblaq Teaching)

\section{The Resource of Education}

From the interviews, it is known that the resources of the Islamic moral teaching at MAN's in Cilacap Regency were supported by the vision and mission of the Islamic moral teaching as defined in the strategic plan. Rusniati and Haq (2014, p. 102) state that a strategic plan is a plan to utilize available resources in order to achieve the goals set by an organization. MAN's in Cilacap Regency position the strategic plan as the implementation guidance for gaining academic achievement and as the vision and mission of the madrasas for the years to come.

In addition to the strategic plan, from the interviews, it is also known that the teachers of the madrasas had been trained to facilitate the students to succeed in the cognitive, psychomotor, and also affective areas. Moreover, Kartowagiran (2011, p. 465) states that teachers are the spearhead of the effort to level up the quality of the service and result of education. Other important factors, in addition to strategic plan and the competence of the teachers, were material and non-material supports from the parents/guardian in the Islamic moral teaching. This is supported by Jalaluddin (2011, p. 291) who argues that, in building Islamic attitude within the children, parents have to provide supports in the elementary education.

\section{The Goals and Scope of the Materials}

Islamic moral teaching aims at providing the students with motivation not only to study aqidah but also to put it into everyday practices. In Islamic studies, morality includes our morality in relation to God and His Prophet, other people, ourselves, and nature. This is in line with previous studies on the similar subjects by Prihatini, Mardapi and Sutrisno (2013, p. 347) who discovered that the construction of Islamic morality encompassed our morality in our relation to Allah subhannabu wa ta'ala, Prophet Muhammad salallahu alaibi wasallam, parents, ourselves, friends, family, community, and nature.

Specifically, in the Islamic moral teaching, the teaching materials cover the materials on good morality, poor morality, stories and examples, and Aqidah (human relationship with Allah SWT). In madrasas, these materials are transformed into materials of Islamic moral teaching.

\section{Facilities and Infrastructure}

The evaluation of the facilities and infrastructure of the madrasas focused on the facilities and infrastructures used in curricular and extracurricular activities. In the curricular activities, there were (1) lesson plan (RPP), (2) the implementation of the lesson plan in the classroom; (3) learning activity manual and 
referential books; and (4) evaluation on the Islamic moral teaching. Whereas, in the extracurricular activities, there were: (1) praying room; (2) praying equipment; (3) facilities and infrastructure for ablution before prayers; and (4) toilets. The condition of each facility and infrastructure is shown in Figure 2.

As shown in Figure 2, overall, the facilities and infrastructures at MAN's in Cilacap are in a good condition. Here are the percentages at each MAN: MAN Cilacap is $88 \%$ (very good), MAN Kroya is 63\% (good) and MAN Majenang is $75 \%$ (good).

The Transaction of Islamic Moral Teaching

The result of the implementation of the Islamic moral teaching in those madrasas is categorized based on the score of each madrasa (see Table 11).

Table 11. The categorization of the result of the transaction of the Islamic moral teaching

\begin{tabular}{ccc}
\hline No. & Score & Categories \\
\hline 1. & $3.25 \leq \mathrm{X}$ & Very Good \\
2. & $2.50 \leq \mathrm{X}<3.25$ & Good \\
3. & $1.75 \leq \mathrm{X}<2.50$ & Poor \\
4. & $\mathrm{X}<1.75$ & Very Poor \\
\hline
\end{tabular}

Generally, the implementation of the Islamic moral teaching at MAN's in Cilacap Regency is in 'good' category. It can be seen from the score of 2.79 with the percentage as high as $70 \%$. The scores for each MAN in Cilacap Regency are presented in Figure 3. As shown by the result, the Islamic moral teaching has been well implemented, following the schedule set and applying an appropriate learning method and technique.

\section{Implementation Time of Islamic Moral teaching}

In terms of the implementation time, the Islamic moral teaching is in a good category scoring 3.08 with percentage of $77 \%$. The details of the implementation at each MAN are shown in Table 12.

Table 12. Scores on the indicator of the implementation time of the Islamic moral teaching

\begin{tabular}{clccc}
\hline Indicator & Madrasa & Score & $\mathbf{0}$ & Categories \\
\hline \multirow{2}{*}{$\begin{array}{l}\text { MANple- } \\
\text { mentation } \\
\text { Time }\end{array}$} & Cilacap & 3.07 & 77 & Good \\
& KaN & 3.58 & 90 & Very Good \\
& MAN & 2.86 & 72 & Good \\
& Majenang & & & Good \\
\hline \multicolumn{2}{c}{ Total } & $\mathbf{3 . 0 8}$ & $\mathbf{7 7}$ & .
\end{tabular}

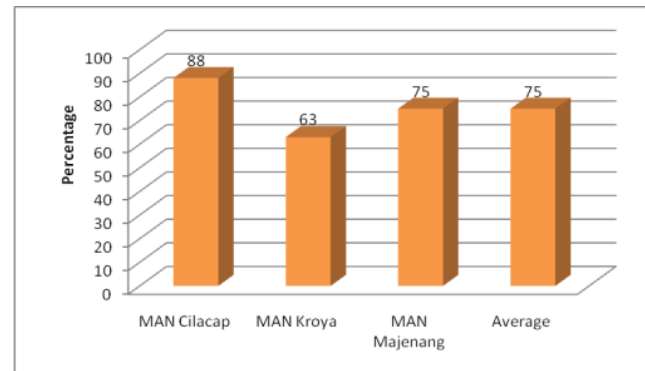

Figure 2. Percentage of facilities and infrastructures for Islamic moral teaching at MAN's in Cilacap Regency

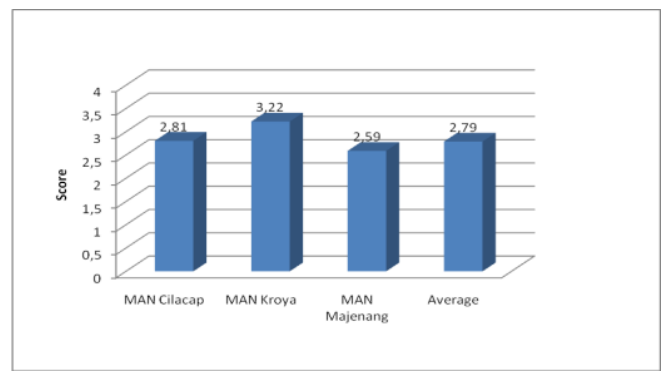

Figure 3. The scores for each MAN in the implementation stage of the Islamic moral teaching 
In this research, the Islamic moral teaching covers curricular activities (learning Aqidah Akblaq in the classroom) and also extracurricular activities. The extracurricular activities in the madrasas are HIMDA'IS (Student's Preachers Association) at MAN Cilacap, An Nisa Study Club at MAN Majenang, and Rohis (Islamic Spiritual and Religious Students Group) at MAN Kroya. Other religious extracurricular activities include: praying together, reading the 99 holy names of Allah, community service, reading the Holy Quran, organizing Islamic Holidays, distributing charity, hajj training, short course on Islamic studies during Ramadhan, Musabaqah Tilawatil Quran (Quran recitation festival), Hadroh Sholawatan (Gathering to praise the Prophet Muhammad SAW), socialization, and also istighozah (gathering to ask Allah for help).

\section{Methods of the Islamic Moral teaching}

The indicator of the method applied in the Islamic moral teaching at MAN's in Cilacap Regency is in a good category. The details are presented in Table 13.

Table 13. Score on the indicator of the methods applied in the Islamic moral teaching

\begin{tabular}{clccc}
\hline Indicator & Madrasa & Score & \% & Category \\
\hline & $\begin{array}{l}\text { MAN } \\
\text { Cilacap }\end{array}$ & 2.88 & 72 & Good \\
Evaluation & MAN & 3.17 & 79 & Good \\
Kethods & $\begin{array}{l}\text { Kroya } \\
\text { MAN }\end{array}$ & 2.66 & 67 & Good \\
& Majenang & $\mathbf{2 . 8 4}$ & $\mathbf{7 1}$ & Good \\
\hline
\end{tabular}

In the Islamic Moral teaching, preaching, providing example, habit formation, giving advice, motivating, and admonishing are the methods used by the teachers. Daradjat (1984, p. 262) and Thoha, et al. (2004, p. 122) state that there are some effective methods in delivering the Islamic moral teaching, including preaching, conducting question-and-answer session, opening discussions, habit formation, providing exemplary actions, and providing advice related to the teaching materials.

\section{Evaluation Model of Islamic Moral Teaching}

The evaluation model of the Islamic moral teaching at these three MAN's in
Cilacap Regency is in a poor category. The reason is that most of the evaluation was conducted only on cognitive aspects. In general, the evaluation put aside the affective aspects. This is in line with previous research which was conducted by Syamsudin, Budiyono and Sutrisno (2016, p. 40) who argue that: 'The elicitation of data from the objects of research has not been as easy as it has been thought because of the behavioral dynamics of the human individuals involved as research subjects..' The details of the scores of the evaluation model of the Islamic moral teaching in each school are elaborated in Table 14.

Table 14. Scores on the indicators of the evaluation model of the Islamic moral teaching

\begin{tabular}{clccc}
\hline Indicator & Madrasa & Score & $\mathbf{\%}$ & Category \\
\hline & $\begin{array}{l}\text { MAN } \\
\text { Cilacap }\end{array}$ & 1.99 & 50 & Poor \\
Evaluation & $\begin{array}{l}\text { MAN } \\
\text { Model }\end{array}$ & 2.42 & 61 & Poor \\
& $\begin{array}{l}\text { Kroya } \\
\text { MAN } \\
\text { Majenang } \\
\text { Average }\end{array}$ & 1.77 & 44 & Poor \\
\hline
\end{tabular}

In the next phase, it is known that the difficulty to measure the affective achievement laid on the fact that the indicator of affective aspects is hard to measure directly. It is possible, but it requires more time spent for observation. In addition, Khuriyah (2003, p. $60)$ in her research states that the construct in the measurement of morality has not been fully developed.

\section{The Outcome of Islamic Moral Teaching}

The outcome of Islamic moral teaching at MAN's in Cilacap Regency is categorized based on the score that each school gained. The details of the categorization are presented in Table 15.

Table 15. The categorization of the outcome of the Islamic moral teaching at MAN's in Cilacap Regency

\begin{tabular}{ccc}
\hline No. & Score & Category \\
\hline 1. & $3.25 \leq \mathrm{X}$ & Very Good \\
2. & $2.50 \leq \mathrm{X}<3.25$ & Good \\
3. & $1.75 \leq \mathrm{X}<2.50$ & Poor \\
4. & $\mathrm{X}<1.75$ & Very Poor \\
\hline
\end{tabular}


In general, based on the data which were collected through the questionnaire, the outcome of the Islamic moral teaching at MAN's in Cilacap Regency reaches the score of 2.99, or it is in a good category. This shows that the students have partially applied good morality in their relation with Allah SWT, the Prophet, other people (social interaction), themselves, and also the nature. The score which is gained by each MAN is shown in Table 16.

Table 16. Scores on the outcome stage of the Islamic moral teaching

\begin{tabular}{ccccc}
\hline Indicator & Madrasa & Score & \% & Category \\
\hline \multicolumn{6}{c}{ MAN } & 3.04 & 76 & Good \\
Cilacap & & & \\
Evaluation & MAN & 3.15 & 79 & Good \\
Kroya & & & \\
& MAN & 2.89 & 72 & Good \\
Majenang & & & \\
Average & $\mathbf{2 . 9 9}$ & $\mathbf{7 5}$ & Good \\
\hline
\end{tabular}

There are two indicators in the outcome of the Islamic moral teaching at MAN's in Cilacap Regency, namely: (1) the application of the Islamic morality inside the area of the madrasas, and (2) the application of the Islamic morality outside the area of the madrasas.

The Implementation of Islamic Morality by Students inside the Area of the Madrasas

In applying Islamic morality in the area of the madrasas, the students of MAN Cilacap gained the score of $3.07(77 \%)$. The students of MAN Kroya scored 3.18 (80\%), and the students of MAN Majenang scored 2.90 $(73 \%)$. In agreement with these scores, during the interviews, the madrasa principals and the teachers stated that, in general, the students applied Islamic morality around the schools well. It is portrayed, evidently, in the behavior and habits of the students. They are friendly, disciplined, soft-spoken, top achievers, and also active in worship and other religious activities. Table 17 and Figure 4 show the score on the implementation of Islamic morality in each Madrasah Aliyah Negeri (MAN) in Cilacap Regency.
Table 17. The score and percentage of the students' application of the Islamic morality in the area of the madrasas

\begin{tabular}{clccc}
\hline Indicator & Madrasa & Score & $\mathbf{\%}$ & Category \\
\hline $\begin{array}{c}\text { Application } \\
\text { of Islamic } \\
\text { morality }\end{array}$ & $\begin{array}{l}\text { MAN } \\
\text { Cilacap }\end{array}$ & 3.07 & 77 & Good \\
inside the & Kroya & 3.18 & 80 & Good \\
madrasas & $\begin{array}{l}\text { MAN } \\
\text { Majenang }\end{array}$ & 2.9 & 73 & Good \\
Average & $\mathbf{3 . 0 1}$ & $\mathbf{7 5}$ & Good \\
\hline
\end{tabular}

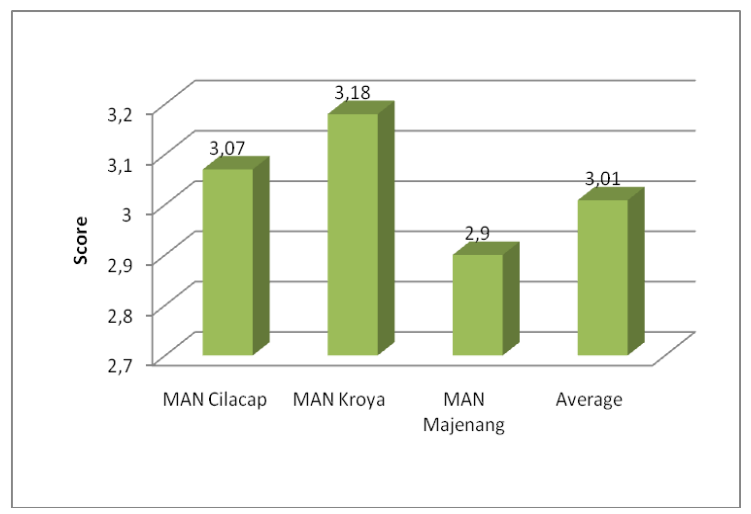

Figure 4. The score of the students' application of Islamic morality in the area of the madrasas

The good category means that Islamic Morality Education in the madrasas had driven the students to be better human beings. This is in line with the definition of education by Marzuki (2009, p. 1) which states that the process of education is a part of the agents of change which shall possess the power to improve the characters of the nation through the improvement of the characters of the students in the education institutions.

\section{The Implementation of Islamic Morality by Students outside the Area of the Madrasas}

There were two indicators in defining the application of Islamic morality - based on the orders of Allah SWT and the teachings of Prophet Muhammad SAW - outside the area of the madrasas: (1) the students' ability to control themselves and shield themselves from promiscuity and negative impacts of technology development, and (2) the students' ability to foster awareness on social issues. The indicator is in a good category with the score of 2.88 and the percentage of $72 \%$. The scores are shown in Table 18 and Figure 5. 
Table 18. The score and percentage of the students' application of the Islamic morality outside the area of the madrasas

\begin{tabular}{|c|c|c|c|c|}
\hline Indicator & Madrasa & Score & $\%$ & Category \\
\hline \multirow{5}{*}{$\begin{array}{l}\text { Application } \\
\text { of Islamic } \\
\text { morality } \\
\text { outside the } \\
\text { madrasas }\end{array}$} & MAN & 2.88 & 72 & Good \\
\hline & Cilacap & & & \\
\hline & MAN & 2.99 & 75 & Good \\
\hline & Kroya & & & \\
\hline & MAN & 2.83 & 71 & Good \\
\hline Aver & & 2.88 & 72 & Good \\
\hline
\end{tabular}

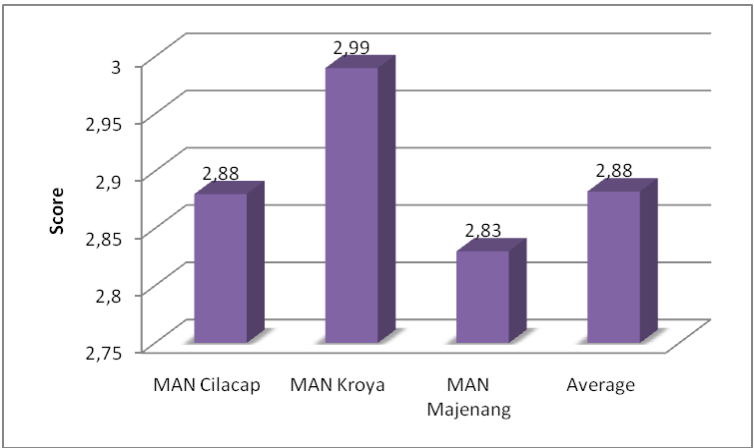

Figure 5. The score of the students' application of the Islamic morality outside the area of the madrasas

The good category means that the students had applied what they had learnt from the Islamic moral teaching outside the area of the madrasas. It was evidenced in their worship activities, their ability to stay away from bad habits and promiscuity, and the negative impacts of technology. They were also able to apply the Islamic morality in the social aspects. The finding in this research is in line with Zuchdi (2013, p. 20) who affirms that the community, represented by colleagues, close friends, co-workers and other parties in the community, has to take part in the development and education of morality of the students as the heirs of the nation.

\section{Conclusions and Recommendations}

Conclusions

Based on the result of the Islamic moral teaching at MAN's in Cilacap Regency, it can be concluded that: (1) the preparatory stage (antecedent) of the Islamic moral teaching, covering resources, goals, material scope, and facilities and infrastructures, scored $75 \%$ or is in a good category; (2) the implementation stage (transaction) of the Islamic moral teaching, covering the implementation time and the method, is in a good category (except for the evaluation model which is in a good category); (3) in general, the outcome of the Islamic moral teaching - the application of Islamic morality inside and outside the area of the madrasas - at MAN's in Cilacap Regency scored $75 \%$ or is in a good category.

\section{Recommendations}

The result of the analysis, i.e the indicator of the evaluation model of the programs of Islamic moral teaching is in a poor category. Therefore, the evaluation aspects of the education need improvement and deeper analysis. The goal is to formulate students' morality criteria objectively. Additionally, the research on the effectiveness of the Islamic moral teaching has to be conducted. It will serve as the follow up of this evaluation, which should serve as the basis for researchers to conduct systematic research on the aspects of Islamic moral teaching, specifically on the morality evaluation techniques and models, the development of the morality evaluation instruments, the effectiveness of the morality teaching methods and the effectiveness of the programs of the Islamic moral teaching.

\section{References}

Abas, Z. Z. (1437). Makarimal Akblak. Cairo: Al Qomar.

Daradjat, Z. (1984). Dasar-dasar pendidikan agama Islam: Buku teks pendidikan agama Islam pada perguruan tinggi umum. Jakarta: Bulan Bintang.

Daradjat, Z. (2000). Ilmu pendidikan Islam. Jakarta: Bumi Aksara.

Darmayanti, S. E., \& Wibowo, U. B. (2014). Evaluasi program pendidikan karakter di sekolah dasar Kabupaten Kulonprogo. Jurnal Prima Edukasia, 2(2), 223234. https://doi.org/10.21831/jpe.v2i2. 2721

Indonesian Department of Religious Affairs. (2011). Al Qur'an dan terjemahnya: Syaamil al Qur'an special for women. Bandung: PT. Sigma Exa Grafika. 
Jalaluddin. (2011). Psikologi agama. Jakarta: Raja Grafindo Persada.

Kartowagiran, B. (2011). Kinerja guru profesional (guru pasca sertifikasi). Cakrawala Pendidikan, 30(3), 463-473. https://doi.org/10.21831/cp.v3i3.4208

Kartowagiran, B., \& Maddini, H. (2015). Evaluation model for Islamic education learning in junior high school and its significance to students' behaviours. American Journal of Educational Research, 3(8), 990-995. https://doi.org/ 10.12691/education-3-8-7

Khuriyah, K. (2003). Pengembangan instrumen evaluasi ranah afektif untuk pedidikan agama Islam. Jurnal Penelitian Dan Evaluasi Pendidikan, 5(6), 59-73. https://doi.org/10.21831/pep.v5i6.205 8

Linn, R. L. (1989). Educational measurement. New York, NY: Macmillan.

Mardapi, D. (2008). Teknik penyusunan instrumen tes dan nontes. Yogyakarta: Mitra Cendekia.

Mardapi, D. (2012). Pengukuran, penilaian, dan evaluasi pendidikan. Yogyakarta: Nuha Medika.

Marzuki. (2009). Prinsip dasar akblak mulia: Pengantar studi konsep-konsep dasar etika dalam Islam. Yogyakarta: Debut Wahana Press.

Miles, M. B., \& Huberman, A. M. (1994). Qualitative data analysis: An expanded sourcebook (2nd ed.). Thousand Oaks, CA: SAGE Publication.
Prihatini, S., Mardapi, D., \& Sutrisno, S. (2013). Pengembangan model penilaian akhlak peserta didik madrasah aliyah. Jurnal Penelitian Dan Evaluasi Pendidikan, 17(2), 347-368. https://doi.org/ 10.21831/pep.v17i2.1705

Retnawati, H. (2016). Validitas reliabilitas \& karakteristik butir (Panduan untuk peneliti, mahasiswa, dan psikometrian). Yogyakarta: Nuha Medika.

Rusniati, \& Haq, A. (2014). Perencanaan strategis dalam perspektif organisasi. Jurnal INTEKNA: Informasi Teknik Dan Niaga, 14(2), 102-209. Retrieved from http://ejurnal.poliban.ac.id/index.php/ intekna/article/view/178

Syamsudin, A., Budiyono, B., \& Sutrisno, S. (2016). Model of affective assessment of primary school students. REiD (Research and Evaluation in Education), 2(1), 25-41. https://doi.org/ 10.21831/reid.v2i1.8307

Thoha, C. (2004). Metodologi pengajaran agama (2nd ed.). Yogyakarta: Pustaka Pelajar.

Worthen, B. R., \& Sanders, J. R. (1973). Educational evaluation: Theory and practice. Worthington, OH: Longman.

Ya'qub, H. (1991). Etika Islam: Pembinaan akblaqulkarimah (suatu pengantar). Bandung: Diponegoro.

Zuchdi, D. (2013). Pendidikan karakter: Konsep dasar dan implementasi di perguruan tinggi. Yogyakarta: UNY Press. 